\title{
Impact of Iron Status of Pregnant Women on the Anthropometry of Newborns in Industrial and Non-Industrial Areas
}

\author{
R. Sachdeva, P. Kaur, A. Kochhar and P. Chawla \\ Department of Food and Nutrition, College of Home Science, Punjab Agricultural University, \\ Ludhiana 141 004, Punjab, India
}

KEYWORDS Pregnancy. Nutrition. Gestational Age. Birth Weight. Anthropometry. Environmental Pollution

\begin{abstract}
Sixty pregnant women [30 each in group I (industrial area) and II (non-industrial area)] in the age group of 20-28 years belonging to low income group (having monthly per capita income of Rs.969.83 and Rs. 631.87) of Bathinda city were selected during $7^{\text {th }}$ month of pregnancy to study the impact of iron status of pregnant women on the anthropometry of their newborns. The mean daily intake of energy, protein, carbohydrates, vit- $\mathrm{B}_{12}$, niacin, iron, folic acid, sodium and zinc was inadequate. Intake of $\beta$-carotene, vit- $\mathrm{B}_{1}$ and $\mathrm{B}_{2}$ was marginally adequate. The higher incidence of anemia was observed (93\%) in group I as compared to group II (83\%). Inadequate iron intake was the cause of poor iron status in both the groups but environmental pollution in group I was major and additional factor contributed to low hemoglobin levels among the subjects. The other haemopoetic indices eg. PCV, MCV, MCH and $\mathrm{MCHC}$ were also lower as compared to the subjects in group II. Incidence of low birth weight was higher in group I (100 $\%)$ as compared to group (76.67\%). Other anthropometric measurements were also lower in the new borns of group I when compared to group II. Thus, besides the remedial techniques, environmental education and awareness programme should be implemented for the masses because "unless the environment is healthy, the individual cannot be healthy".
\end{abstract}

\section{INTRODUCTION}

Pregnancy is one of the most critical and unique period of women's life cycle. Though, it is the most exciting period of expectations and fulfillments, but it is a condition of great stress because many anabolic activities take place and foetal growth is accomplished by extensive changes in maternal body composition and metabolism. Maternal nutrition is the most important determinant influence during the development of foetus. Poor nutrional status during pregnancy is associated with inadequate weight gain, anaemia, retarded foetal growth, low birth weight, still births, preterm delivery, IUGR (intrauterine growth retardation), morbidity and mortality rates (Kansel et al. 2003). Thus, it may threaten the health and life of the mother and the newborn.

Anaemia is one of the most prevalent public health problem in India being termed as "silent epidemic" by Indian Medical Association. Prevalence of iron deficiency anaemia exceeds 80 per cent among pregnant women (Gupta and Gupta 2006). It is directly or indirectly responsible for 20 per cent maternal deaths and a significant contributor to feotal wastage, premature births and low birth weight (Mehta and Dood 2004). Anemia induces irreversible changes in placental morphology, marphometry and histology. Anemic women have poor resistance to infections and are likely to suffer from complications.

Environmental pollution is a growing problem of mankind because it affects the health and nutritional status of an individual. Pollution is common especially in industrial cities where despite the legal restrictions, factories and sewage works dump dangerous substances like fertilizers, chemicals, heavy metals and other industrial wastes in the rivers and air. Thus water, food chain and air are adversely affected by pollution which result into many diseases like respiratory diseases, infectious diseases like typhoid, diarrhea, dysentery, cancer, immuno-toxicity, reproduction defects etc. (Eastwood 2002). In the rapid industrialization, countries such as China and India, iron deficiency can magnify the already devastating effects of pollution. Iron deficiency creates a susceptibility to toxic substances viz. heavy metals, pesticides, chemicals and radioactive substances that can in-turn work to undermine the immune system and general functioning of the body including the symptoms such as fatigue, learning disabilities, stunted growth, physical disability and reduced resistance to disease. Maternal exposure to air pollution adversely impacts birth outcomes such as low birth weight, preterm delivery, IUGR (intrauterine growth retardation) and post neonatal infant mortality etc. (Bell et al. 2007). Considering 
the effect of pollution, the present study was undertaken to explore the impact of iron status of pregnant women on the anthropometry of their newborns.

\section{MATERIALS AND METHODS}

Selection of the Subjects: A statistically adequate sample of sixty pregnant women aged 20-28 years belonging to low income group were selected and divided equally into two groups viz. group I (Industrial) and group II (Non-industrial area). Group II comprised of 15 subjects each from Guru Nanak Dev Thermal Plant and National Fertilizers Limited, Bathinda city and subjects of group II were selected from Village Bandi (Bathinda district), $30 \mathrm{~km}$ away from group I, being non-polluted from industrial pollution.

Collection and Analysis of Data: Background information pertaining to age, education, total and per capita income, life style, economic status, living conditions and obstetric history etc. were elicited through the interview schedule. Nutrient intake was calculated by "MSU nutriguide" (Song et al. 1992). Blood samples were analysed for Haemoglobin (Hb), Packed Cell Volume (PCV) and Red Blood Cell (RBC) Count. Mean Corpuscular Volume (MCV), Mean Corpuscular Haemolglobin $(\mathrm{MCH})$ and Mean Corpuscular Haemoglobin Concentration (MCHC) were calculated during $7^{\text {th }}$ and $9^{\text {th }}$ months of pregnancy.

Anthropometric Measurements: Anthropometric measurements of newborns viz. birth weight, crown heel length, head circumference, chest circumference, mid-upper arm circumference were taken within 24 hours of their birth by the standard methods described by Jelliffe (1966). Roher's Ponderal Index was also calculated by following formula:

$$
\text { Ponderal index }=\frac{\text { Birth weight }(\mathrm{g})}{[\text { Crown heel length }]^{3}} \times 100
$$

Statistical Analysis: The data was analyzed with the help of various statistical tools such as mean, standard error and percentage. Student's t-test was applied. Pearson's correlation coefficient was worked out.

\section{RESULTS AND DISCUSSION}

As per the demographic information, the mean age of the subjects was $23.5 \pm 2.1$ and $24.1 \pm 2.0$ in group I and group II, respectively. Majority (46.66 and 26.67 per cent) were educated up to middle in both the groups and the remaining 36.67 and 33.33 per cent were literate in both the groups, respectively. The level of education was recorded to be higher in group I (83.33 per cent) as compared to Group II (60 per cent). Statistical data reported that only 57 and 63.55 per cent females were literate in India and Punjab (Anonymous 2007). The information regarding the occupation and economic status of the subjects depicted that most of the subjects in both the groups were housewives (100 and 93.33 per cent) and remaining 6.67 per cent were maid servants in group II. Further, it was observed that majority of the husbands of the subjects were agricultural labourers and shopkeepers in Group II whereas all the husbands of the subjects in Group I were workers in fertilizer factory and thermal plant. The average monthly per capita income was Rs. 969.83 and 631.87 in Group I and II, respectively. While the average per capita income at constant prices was 30701 (Anonymous 2007). Living conditions and hygiene status were poor in the Group I. The data revealed that majority (56.67 and 66.67 per cent) of the subjects were in primipara while the remaining 26.67 and 26.67 per cent in second, 16.67 per cent in terci in Group I and 6.67 per cent in multipara in Group II. It was observed that very few subjects visited anganwadis and Primary Health Centre for health services and medical treatment. Very few subjects took iron supplements in both the groups. Lack of awareness was the main cause for not taking supplements.

\section{Nutrient Intake}

Table 1 depicted that the mean daily intake of energy by the subjects was $1712.3 \pm 158.7$ and $1635.6 \pm 201.6$ and $1920.3 \pm 124.8$ and $1826.5 \pm 181.7$ kcal. during both the months of pregnancy. The intake of energy was increased during $9^{\text {th }}$ month and could be due to increased consumption of cereals, sugar and jaggery and fats and oils. The mean daily intake of protein in the two groups was $50.5 \pm 4.5$ and $49.6 \pm 5.8$ and $56.2 \pm 4.3$ and $55.5 \pm 5.2 \mathrm{~g}$, respectively. The mean daily intake of carbohydrate was 241.6 \pm 24.6 and $231.9 \pm 31.7$ and $269.5 \pm 19.5$ and $272.3 \pm 33.7 \mathrm{~g}$ in both the groups, respectively. The mean daily intake of fats and oils was $60.4 \pm 7.3$ and $56.6 \pm 7.4$ and $68.6 \pm 6.0$ and $61.2 \pm 6.7 \mathrm{~g}$ during both the months, respectively. The higher intake of fats and oils in both the groups during $9^{\text {th }}$ month and 
Table 1: Average daily nutrient intake of the subjects

\begin{tabular}{|c|c|c|c|c|c|c|c|}
\hline \multirow[t]{2}{*}{ Food items } & \multicolumn{3}{|c|}{$7^{\text {th }}$ Month } & \multicolumn{3}{|c|}{$9^{\text {th }}$ Month } & \multirow[b]{2}{*}{$R D A *$} \\
\hline & $\begin{array}{c}\text { Group-I } \\
(n=30) \\
\text { Average } \pm S E\end{array}$ & $\begin{array}{c}\text { Group-II } \\
(n=30) \\
\text { Average } \pm S E\end{array}$ & $t$-value & $\begin{array}{c}\text { Group }-I \\
(n=30) \\
\text { Average } \pm S E\end{array}$ & $\begin{array}{c}\text { Group-II } \\
(n=30) \\
\text { Average } \pm S E\end{array}$ & $t$-value & \\
\hline Energy (Kcal.) & $1712.3 \pm 158.7$ & $1635.6 \pm 201.6$ & $1.655^{\mathrm{NS}}$ & $1920.3 \pm 124.8$ & $1826.5 \pm 181.7$ & $1.402^{\mathrm{NS}}$ & 2175 \\
\hline Protein $(\mathrm{gm})$ & $50.5 \pm 4.5$ & $49.6 \pm \quad 5.8$ & $0.648^{\mathrm{NS}}$ & $56.2 \pm \quad 4.3$ & $55.5 \pm 5.2$ & $0.561^{\mathrm{NS}}$ & 65 \\
\hline Carbohydrates (gm) & $241.6 \pm 24.6$ & $231.9 \pm 31.7$ & $1.322^{\mathrm{NS}}$ & $269.5 \pm 19.5$ & $272.3 \pm 33.6$ & $0.389 \mathrm{NS}$ & 353 \\
\hline Total fats $(\mathrm{gm})$ & $60.4 \pm \quad 7.3$ & $56.6 \pm \quad 7.4$ & $1.998 \mathrm{NS}$ & $68.6 \pm 6.0$ & $61.2 \pm \quad 6.7$ & $4.427 * *$ & 55 \\
\hline$\beta$ Carotene $(\mu \mathrm{g})$ & $2266.0 \pm 128.7$ & $2688.2 \pm 109.0$ & $4.170 * *$ & $1776.6 \pm 174.6$ & $1880.3 \pm 203.3$ & $2.242 * *$ & 2400 \\
\hline Retinol $(\mu \mathrm{g})$ & $947.5 \pm 430.8$ & $982.5 \pm 452.5$ & $0.306^{\mathrm{NS}}$ & $885.5 \pm 90.3$ & $885.3 \pm 327.3$ & $0.004^{\mathrm{NS}}$ & 600 \\
\hline Thiamine (mg) & $1.1 \pm 0.1$ & $1.0 \pm 0.1$ & $2.990 * *$ & $1.1 \pm 0.1$ & $1.0 \pm \quad 0.1$ & $4.486 * *$ & 1.1 \\
\hline Riboflavin (mg) & $1.0 \pm$ & $0.0 \pm$ & $2.862 * *$ & $1.2 \pm$ & $1.2 \pm$ & $2.543 * *$ & 1.3 \\
\hline Niacin (mg) & $11.7 \pm$ & $11.0 \pm$ & $1.726^{\mathrm{NS}}$ & $12.9 \pm$ & $12.6 \pm$ & $0.868 \mathrm{NS}$ & 14 \\
\hline $\mathrm{B}_{12}(\mathrm{mg})$ & $0.5 \pm \quad 0.0$ & $0.5 \pm \quad 0.1$ & $0.130^{\mathrm{NS}}$ & $0.6 \pm \quad 0.0$ & $0.6 \pm \quad 0.0$ & $0.960^{\mathrm{NS}}$ & 4.0 \\
\hline Folic acid $(\mu \mathrm{g})$ & $258.8 \pm 65.5$ & $283.0 \pm 91.9$ & $1.865^{\mathrm{NS}}$ & $246.6 \pm 74.5$ & $274.6 \pm 70.8$ & $1.689 \mathrm{NS}$ & 400 \\
\hline Vitamin-C (mg) & $43.6 \pm 14.8$ & $46.1 \pm 27.8$ & $1.545 * *$ & $41.9 \pm 12.9$ & $43.0 \pm 14.6$ & $1.022 \mathrm{NS}$ & 40 \\
\hline
\end{tabular}

* ICMR (1999)

** Significant at 5\% level

Ns Non-significant at $5 \%$ level

could be due to more consumption of desi ghee (butter oil) and hydrogenated fat by most of the subjects as they used to put extra ghee in milk, vegetables, Saag and pulses. The average daily intake of $\beta$ - carotene was adequate duing $7^{\text {th }}$ month but decreased in $9^{\text {th }}$ month due to less availability of green leafy vegetables. The intake of retinol, and vitamin- $\mathrm{C}$ was more than adequate due to consumption of carrots, green leafy vegetables and citrus fruits whereas the intake of vit-B1, B2, niacin and folic acid was inadequate. Low intake of vit-B12 among the subjects might be due to lack of non vegetarian foods in their diet. It was clearly related to poor purchasing power of the subjects.

\section{Mineral Intake}

Table 2 depicts the mineral intake of the subjects. The mean daily intake of iron decreased during $9^{\text {th }}$ month in both groups because of decreased intake of green leafy vegetables and jaggery. The intake of calcium, phosphorus, potassium and magnesium was more than adequate due to higher intake of milk and milk products and bananas. Intake of iron, sodium and zinc met less than 50 per cent of the total requirements as suggested by ICMR (1999).Similarly Pathak et al. (2004) reported that nearly $73.5,2.7,43.6,73.4,26.3$ and 6.4 per cent pregnant women were deficient in zinc, copper, magnesium, iron, folic acid and iodine, respectively and over 90 per cent of pregnant women were consuming the nutrients even less than 50 per cent of the recommended intake. Similar results have also been reported by Shobeiri et al. (2003)

\section{Haemopoetic Profile of the Subjects}

Table 3 depicts the haemopoetic profile of

Table 2: Average daily intake of minerals among the subjects

\begin{tabular}{|c|c|c|c|c|c|c|c|}
\hline \multirow[t]{2}{*}{ Food items } & \multicolumn{3}{|c|}{$7^{\text {th }}$ Month } & \multicolumn{3}{|c|}{$9^{\text {th }}$ Month } & \multirow[b]{2}{*}{$R D A *$} \\
\hline & $\begin{array}{c}\text { Group }-I \\
(n=30) \\
\text { Average } \pm S E\end{array}$ & $\begin{array}{c}\text { Group-II } \\
(n=30) \\
\text { Average } \pm S E\end{array}$ & t-value & $\begin{array}{c}\text { Group-I } \\
(n=30) \\
\text { Average } \pm S E\end{array}$ & $\begin{array}{c}\text { Group-II } \\
(n=30) \\
\text { Average } \pm S E\end{array}$ & t-value & \\
\hline Calcium (mg) & $897.1 \pm 139.0$ & $867.5 \pm 139.0$ & $0.892^{\mathrm{NS}}$ & $903.5 \pm 171.9$ & $887.7 \pm 129.3$ & $0.849^{\mathrm{NS}}$ & 1000 \\
\hline Phosphorus(mg) & $1311.2 \pm 129.1$ & $1257.2 \pm 163.1$ & $1.421 \mathrm{NS}$ & $1463.2 \pm 116.2$ & $1426.8 \pm 142.6$ & $1.084^{\mathrm{NS}}$ & 1200 \\
\hline Sodium (mg) & $153.3 \pm 24.0$ & $151.0 \pm 16.2$ & $0.428^{\mathrm{NS}}$ & $130.9 \pm 19.9$ & $126.2 \pm 23.1$ & $0.428^{\mathrm{NS}}$ & 500 \\
\hline Potassium (mg) & $1593.6 \pm 148.9$ & $1567.6 \pm 198.8$ & $0.574^{\mathrm{NS}}$ & $1842.3 \pm 159.3$ & $1813.1 \pm 193.4$ & $0.638^{\mathrm{NS}}$ & $\begin{array}{r}800- \\
1300\end{array}$ \\
\hline Magnesium(mg) & $306.6 \pm 37.7$ & $290.0 \pm 51.8$ & $1.421^{\mathrm{NS}}$ & $357.3 \pm 28.0$ & $356.9 \pm 50.2$ & $0.041^{\mathrm{NS}}$ & 300 \\
\hline Zinc $(m g)$ & $5.2 \pm \quad 0.6$ & $48 \pm \quad 0.8$ & $2.338 * *$ & $6.03 \pm 0.66$ & $5.8 \pm \quad 0.7$ & $2.891 * *$ & 14 \\
\hline
\end{tabular}


the subjects. The mean hemoglobin level was $9.3 \pm 0.6$ and $9.8 \pm 1.01$ and $9.5 \pm 0.7$ and $10.0 \pm 0.9 \mathrm{~g} /$ dl. in Group I and II during $7^{\text {th }}$ and $9^{\text {th }}$ months, respectively. Poor hemoglobin levels could be due to low iron intake, poor sanitation, high morbidity status in both the groups but in group I, environmental pollution was the additional factor. Values of Packed Cell Volume (PCV) were $27.5 \pm 2.1$ and $27.6 \pm 2.5$ and $29.7 \pm 2.2$ and $31.0 \pm 1.5$ per cent Red Blood Cell (RBC) count were 3.5 \pm 0.3 and $3.5 \pm 0.2$ and $3.5 \pm 0.3$ and $3.6 \pm 0.2 \times 10^{6} \mathrm{~mm} 3$ in both the groups, during $7^{\text {th }}$ and $9^{\text {th }}$ months of pregnancy and were lower than the standards (Hunter and Bomford 1967). The values of Mean Corpuscular Volume (MCV) were 73.5 \pm 4.9 and $78.5 \pm 4.1$ and $75.9 \pm 4.9$ and $80.8 \pm 5.0 \mathrm{fl}$, Mean Corpuscular Hemoglobin $(\mathrm{MCH})$ were $27.8 \pm 1.9$ and $27.5 \pm 1.6$ and $27.9 \pm 2.0$ and $28.1 \pm 2.1 \mathrm{pg}$ and Mean Corpuscular Hemoglobin Concentrate (MCHC) were 29.8 \pm 1.9 and $29.5 \pm 1.6$ and $29.9 \pm 1.9$ and $30.1 \pm 2.1 \mathrm{~g} / \mathrm{dl}$ which were within the range (Passmore and Eastwood 1987) in two groups during both the months, respectively. Fernando and Berger (2005) reported that pregnant women were at the higher risk of anemia in many industrialized countries and more than 80 per cent cases of anemia in women, especially during pregnancy were associated with iron deficiency component. Whereas Gupta and Gupta (2006) studied 3099 young female population in villages around Bathinda city and showed that anemia was present in 89.5 per cent $(2775 / 3099)$ females in rural Punjab. It has been stressed that it resulted in the impairment of mental, motor development and behavior of the infants.

\section{Anthropometric Measurements of Newborns}

Anthropometric measurements of newborns in group I as compared to the newborns in group II is presented in Table 4 . The mean birth weight was $1923.3 \pm 359.0$ and $2320.0 \pm 426.3 \mathrm{~g}$ in group I and II, respectively. A significantly ( $\mathrm{p} \leq 0.05)$ lower birth weight was observed in group I as compared to group II, because of high exposure of environmental pollutants and higher rate of prematurity as the mean gestational age of the newborns in group I and II was $34.2+3.7$ and $38.4+0.9$ weeks.

Table 3: Heamopoetic indices of pregnant women

\begin{tabular}{|c|c|c|c|c|c|c|c|}
\hline \multirow[t]{3}{*}{ Blood analysis } & \multicolumn{3}{|c|}{$7^{\text {th }}$ Month } & \multicolumn{3}{|c|}{$9^{\text {th }}$ Month } & \multirow{3}{*}{$\begin{array}{c}R D A * \\
(1999)\end{array}$} \\
\hline & $\begin{array}{c}\text { Group-I } \\
(n=30)\end{array}$ & $\begin{array}{c}\text { Group-II } \\
(n=30)\end{array}$ & & $\begin{array}{c}\text { Group-I } \\
(n=30)\end{array}$ & $\begin{array}{c}\text { Group-II } \\
(n=30)\end{array}$ & & \\
\hline & Average $\pm S E$ & Average $\pm S E$ & t-value & Average $\pm S E$ & Average $\pm S E$ & t-value & \\
\hline Haemoglobin (g/dl) & $9.3 \pm 0.6$ & $9.8 \pm 1.0$ & $0.166^{\mathrm{NS}}$ & $9.5 \pm 0.7$ & $10.0 \pm 0.9$ & 0.471 NS & $11^{+}$ \\
\hline Hematocrit $(\%)$ & $27.5 \pm 2.5$ & $27.6 \pm 2.1$ & $0.178^{\mathrm{NS}}$ & $29.7 \pm 2.2$ & $31.0 \pm 1.5$ & $0.807^{\mathrm{NS}} 3$ & $32-36^{+}$ \\
\hline $\begin{array}{l}\text { Red blood cell count } \\
\left(\mathrm{x} 10^{6} \mathrm{~mm}^{3}\right)\end{array}$ & $3.5 \pm 0.3$ & $2.5 \pm 0.2$ & $0.222^{\mathrm{NS}}$ & $3.5 \pm 0.3$ & $3.6 \pm 0.2$ & $0.846^{\mathrm{NS}}$ & $.0-5.5^{++}$ \\
\hline $\operatorname{MCV}(\mathrm{g} / \mathrm{dl})$ & $73.5 \pm 4.9$ & $78.5 \pm 4.1$ & $0.771^{\mathrm{NS}}$ & $75.9 \pm 4.9$ & $80.8 \pm 5.0$ & $0.714^{\mathrm{NS}}$ & $5-95^{++}$ \\
\hline $\mathrm{MCH}$ (pg.) & $27.8 \pm 1.9$ & $27.5 \pm 1.6$ & $0.756^{\mathrm{NS}}$ & $27.9 \pm 2.0$ & $28.1 \pm 2.1$ & $0.700^{\mathrm{NS}}$ & $7-32^{++}$ \\
\hline $\mathrm{MCHC}(\mathrm{g} / \mathrm{dl})$ & $29.8 \pm 1.9$ & $29.5 \pm 1.6$ & $0.749^{\mathrm{NS}}$ & $29.9 \pm 1.9$ & $30.1 \pm 2.1$ & $0.685^{\mathrm{NS}} 3$ & $30-36^{++}$ \\
\hline
\end{tabular}

* Significant at $5 \%$ level

Ns Non-significant at $5 \%$ level

+ Hunter and Bamford (1967)

++ Passmore and Eastwood (1987)

Table 4: Anthropometric measurements of the newborns

\begin{tabular}{|c|c|c|c|c|}
\hline Anthropometric measurements & $\begin{array}{c}\text { Group }-I(n=30) \\
\text { Average } \pm S E\end{array}$ & $\begin{array}{c}\text { Group }-I I(n=30) \\
\text { Average } \pm S E\end{array}$ & $t$-value & ICMR8 Standards \\
\hline Birth weight (gm) & $1923.3 \pm 3.59 .0$ & $2320.0 \pm 426.3$ & $2.682 * *$ & $2700-2800$ \\
\hline Crown-Heel length $(\mathrm{cm})$ & $45.9 \pm \quad 3.7$ & $47.9 \pm 2.6$ & $2.581 * *$ & $47.7-48.5$ \\
\hline Head circumference $(\mathrm{cm})$ & $28.7 \pm$ & $30.1 \pm$ & $2.247 * *$ & $32.6-33.5$ \\
\hline Chest circumference $(\mathrm{cm})$ & $30.3 \pm$ & $31.6 \pm$ & $2.218 * *$ & $30.2-33.5$ \\
\hline Mid-upper-arm circumference $(\mathrm{cm})$ & $9.8 \pm$ & $10.1 \pm$ & 0.827 & $12.0-12.2$ \\
\hline Ponderal index & $1.8 \pm$ & $2.1 \pm$ & $2.112 * *$ & $2.25-2.85$ \\
\hline Gestational age (weeks) & $34.2 \pm$ & $38.4 \pm$ & $3.310 * *$ & $38-42$ \\
\hline
\end{tabular}

* Gupta (1978)

** Significant at 5\% level

Ns Non-significant at 5\% level 
Bell et al. (2007) reported that an inter-quartile increase in gestational exposure to $\mathrm{NO} 2, \mathrm{CO}$, PM10 and PM2.5 (particulate matter with aerodynamic diameter $<10,<2.5 \mu \mathrm{m}$ ) lowered the birth weight by $8.9 \mathrm{~g}, 8.2 \mathrm{~g}$ and $14.7 \mathrm{~g}$, respectively. Gouveia et al. (2004) also reported that exposure of $1 \mathrm{ppm}$ of $\mathrm{CO}$ increase was inversely related to $23 \mathrm{~g}$ reduction in birth weight. Other anthropometric measurements viz. crown heel length $(45.9 \pm 3.7 \mathrm{Vs} 47.9 \pm 2.6 \mathrm{~cm})$, head circumference $(28.7 \pm 2.9 \mathrm{Vs} 30.1 \pm 2.4 \mathrm{~cm})$, chest circumference $(30.3 \pm 2.8 \mathrm{Vs} 31.6 \pm 2.5 \mathrm{~cm})$ and midupper arm circumference $(9.8 \pm 1.4 \mathrm{Vs} 10.1 \pm 1.3 \mathrm{~cm})$ were also lower in the newborns in group I as compared to the newborns in group II. Ponderal index can be used to detect aberrant intra-uterine growth independent to gestational age. The average value of Ponderal index was also lower in group I $(1.8 \pm 0.2)$ as compared to group II $(2.1 \pm 1.2)$ but lower than the reference standard (ICMR 1999) in both the groups due to low birth weight and crown heel length. Pharaoh (2003) reported that low birth weight would be either due to preterm delivery due to exposure of pregnant women to environmental toxins like DDT and other pesticides which led to intra-uterine growth retardation and less gestational age of the newborns. Wilhelm and Ritz (2003) also reported that 10-20 per cent risk of premature birth and low birth weight for infants born to the women living near high traffic areas or industrial areas.

\section{CONCLUSIONS}

In brief, the perusal data clearly indicated that poor nutrient intake, iron status and biochemical assessment were indicator of the state of under nutrition among the pregnant women. So, it can be concluded that poor nutrient intake, iron deficiency anemia resulted in low birth weight babies in both the groups. The situation worsened in group I due to maternal exposure to pollutants as all the infants were LBW and gestational age was also lower.

\section{RECOMMENDATIONS}

There is need to focus attention on environmental education and sanitation. Besides the remedial techniques, new schemes and laws should be proposed and employed strictly to minimize the environmental pollution and maintain sanitary conditions as it resulted to poor birth outcome. Nutrition education should be imparted by dieticians and extra nutritional care should be given by health workers through mobile dispensaries, work shops and camps. Infrastructure of health services should be strengthened to provide primary health care to the mothers.

\section{REFERENCES}

Anonymous 2007. India: A Reference Manual. New Delhi: Ministry of Information and Broadcasting, Government of India, pp. 8-13.

Bell ML, Ebiser K, Belanger C 2007.Ambient air pollution and low birth weight in Connecticut and Massachusetts. Environ. Health Perspect, 115: 1118-1124.

Eastwood M 2002. Principles of Human Nutrition. New Delhi: Antlantic Publishers and Distributors, P. 23.

Fernando EV, Berger J 2005. Importance of prepregnancy and pregnancy iron status: can long term weekly preventive iron and folic acid supplementation achieve desirable and safe status? Nutr Reviews, 63(12): S65-S76.

Gouveia N, Bremer SA and Novaes HM 2004. Association between ambient air pollution and birth weight in Sao Paulo. Brazil J Epideml Comm Health, 58(1): $11-17$.

Gupta S 1978. A Text Book of Pediatrics. New Delhi: Vikas Publishing House Pvt. Ltd., P. 35

Gupta V, Gupta S 2006. Prevalence of anaemia in young males and females in rural Punjab. Abstract of the paper presented at $61^{\text {st }}$ annual conference of the association of physicians of India from $30^{\text {th }} \mathrm{Jan}$. to $2^{\text {nd }}$ Feb. 2006 at Patna. .

Hunter I, Bomford VN 1967. Clinical haematology. New York: Academic Press, P. 11.

ICMR 1999. Dietary Guidelines for Indians A Manual. Hyderabad: NIN (ICMR).

Jelliffe DB 1966. The Assessment of the Nutritional Status of Community. World Health Organization Monograph series no. 53, Geneva: WHO.

Kansal B, Guleria K, Agarwal N, Sethi K 2004. Effect of maternal nutritional supplementation on fetal growth parameters and doppler flow velocity in growth restricted fetuses. Ind J Nutr Dietet, 41: 198204.

Mehta MB, Dood NS 2004. Effect of different levels of iron status of iron supplementation on maternal iron status and pregnancy outcome. Ind $J$ Nutr Dietet, 41: 467-76.

Pathak P, Kapil U, Kapoor SK, Sexana R, Kumar A, Gupta N, Dwivedi SN, Singh R, Singh P 2004. Prevalence of multiple micronutrient deficiencies amongst pregnant women in a rural area of Haryana. Ind Pediatrics, 71: 1007-1114.

Passmore R, Eastwood MA 1987. Human Nutrition and Dietetics. Hong Kong: English Language Books Society, P. 460.

Pharaoh CA 2003. Relation between ambient air pollution and low birth weight in northeastern United States. Environ Health Perspective, 109: 351-356.

Shobeiri F, Begum K, Nazari P 2003. A prospective study 
of maternal haemoglobin status of Indian women during pregnancy and pregnancy. Abstract reviews, cited from doi: 10.1016/j.nutres.2006.05. 008

Song WO, Roere S, Bond J, Kalarala M, Mann S, Sehgal S, Pande U, Singh I, Mehta U, Rohindeva P 1992. A
Nutritional Analysis Computer Programme, Michigan: Michigan State University.

Wilhelm M, Ritz S 2003. Residential proximity to traffic and adverse birth outcomes in Los Angeles, California. Environ Health Perspect, 111: 207-216. 